\title{
Role of resveratrol on the cytotoxic effects and DNA damages of iododeoxyuridine and megavoltage radiation in spheroid culture of U87MG glioblastoma cell line
}

\author{
Fariba Firouzi ${ }^{1}$, Samideh Khoei ${ }^{2,3}$ and Hamid R. Mirzaei ${ }^{4}$ \\ 1 Radiology Technology Department, School of Paramedicine, Shahid Beheshti University of Medical Sciences, Tehran, Iran \\ 2 Medical Physics Department, School of Medicine, Iran University of Medical Sciences, Tehran, Iran \\ 3 Razi Drug Research Centre, Iran University of Medical Sciences, Tehran, Iran \\ 4 Oncology Department, Shohada-E Tajrish Hospital, Shahid Beheshti University of Medical Sciences, Tehran, Iran
}

\begin{abstract}
The purpose of this study was to evaluate the effect of resveratrol on cytogenetic damages of iododeoxyuridine (IUdR) and x-ray megavoltage radiation (6 MV) in spheroid model of U87MG glioblastoma cancer cell line using clonogenic and alkaline comet assay. Cells were cultured as spheroids $(350 \mu \mathrm{m})$ that were treated with $20 \mu \mathrm{M}$ resveratrol, $1 \mu \mathrm{M}$ IUdR and 2 Gy of $6 \mathrm{MV}$ x-ray. After treatment, viability of the cells, colony forming ability and the induced DNA damages were examined using trypan blue dye exclusion, colonogenic and alkaline comet assay, respectively. Our results showed that resveratrol could significantly reduce the colony number and induce the DNA damages of the cells treated with IUdR in combination with $6 \mathrm{MV}$ x-ray radiation. That results indicated that resveratrol as an inhibitor of hypoxia inducible factor 1 alpha (HIF-1a) protein in combination with IUdR as a radiosensitizer enhanced the radiosensitization of glioblastoma spheroid cells.
\end{abstract}

Key words: Resveratrol - Iododeoxyuridine - HIF-1 1 - Colonogenic assay - Comet assay - Megavoltage radiation

\section{Introduction}

Malignant gliomas are the most common and deadly intracranial tumors in human being. This tumor includes $50 \%$ of total malignant tumors of central nervous system (Van Meir et al. 2010). The life expectancy of patients with glioblastoma (GBM), using the current standards of care including surgery, radiotherapy and chemotherapy is on average 14 months. For years radiotherapy has been one of the important candidates to the treatment of these tumors. Although the ionizing radiation hasn't changed, but the ability to focus the beam and fit it to tumors and reducing the dose received by nearby critical structures have been noticeably improved (Van Meir et al. 2010). One of the approaches to improve the radiation treatment effi-

Correspondence to: Samideh Khoei, Razi Drug Research Centre, Medical Physics Department, School of Medicine, Iran University of Medical Sciences, P.O.Box: 14155-5983, Tehran, Iran

E-mail: khoei.s@iums.ac.ir skhoei@gmail.com ciency is using radiosensitizers. Iododeoxyuridine (IUdR) is a halogenated thymidine analogue which incorporates into DNA in synthetic phase and sensitizes the tumor cells against ionizing radiation (Speth et al. 1989). Although the exact mechanism of IUdR hasn't been understood, but it is hypothesized that IUdR induces formation of single strand break (SSB) and double strand break (DSB) and leads cells to death. Furthermore, the extent of radiosensitization correlates with the level of IUdR-DNA incorporation (Kinsella et al. 2007).

Multicellular spheroid has been proposed as a model of early tumor growth from which a better understanding of tumor cell heterogeneity and its effects on treatment response might be gained. They are a pattern of solid tumors (in vivo) in a 3-dimentional structure in vitro. So it can estimate the growth and micro environmental condition of real tumors. The absorption of IUdR decreases as spheroid grows in size (Yuhas and Li 1978). On the other hand, by increasing the size of spheroid and creating the hypoxic cells, expression of hypoxia inducible factor 1 alpha (HIF-1 $\alpha$ ) is stimulated (Menrad et al. 2010). 
One of the major causes of cell cycle arrest and leading cells to $\mathrm{G}_{0}$ phase in hypoxic condition is activation of HIF1a protein (Iida et al. 2002). In normoxic condition, HIF1a is marked by prolin_hydroxylase_2 and degraded by proteasome. However, in hypoxic condition, as hydroxylase, von Hippel-Lindau (VHL) proteins and HIF are all depressed by a lack oxygen, HIF1 $\alpha$ is stable and active (Ke and Costa 2006). HIF1a is a main regulator of oxygen homeostasis within cells (Yoon et al. 2013). Under hypoxic condition, HIF1 binds the regulatory region of VEGF and induces its expression. As a result of it, endothelial cells migrate towards hypoxic area and form new blood vessels (Kaur et al. 2005). It has been reported that over expression of HIF1 induces apoptosis in alveolar epithelial cells by stabilizing p53 proteins and causing cell death (Krick et al. 2005). Resveratrol, a polyphenolic compound and naturally occurring phytochemical agent, has been shown to induce growth inhibition, S-phase arrest and apoptosis in several human cancer cell lines (Joe et al. 2002). Furthermore, resveratrol inhibits HIF1 $\alpha$ and VEGF expressions (Kim et al. 2013, 2014). Resveratrol didn't change HIF1a mRNA level in the cells, suggesting that resveratrol influences HIF1a protein synthesis or degradation (Wu et al. 2008). Also it has been proved that resveratrol inhibits cell proliferation and induction of $G_{0} / G_{1}$ growth arrest by the suppression of cyclin D1 expression (Benitez et al.2007). Interestingly no side effect has been seen so far (Aluyen et al. 2012). Therefore, in the present study, we have investigated the combined effect of resveratrol and $\mathrm{x}$-ray megavoltage radiation on the cytogenetic damages caused by IUdR in the spheroid model of the U87MG glioblastoma cell line. U87MG is an established cell line that can self-assemble into large, stable spheroids through a combination of intracellular communication and diffusion. In this study, we used spheroids with $350 \mu \mathrm{m}$ diameters. This guarantees the existence of hypoxic cells.

\section{Materials and Methods}

\section{Cell line}

Human glioblastoma cell line, U87MG, was purchased from the Pasteur Institute of Iran. This cell line was maintained in MEM (PAA laboratories, $\mathrm{GmbH}$, Austria) supplemented with $10 \%$ fetal bovine serum (FBS) (PAA), $100 \mathrm{U} / \mathrm{ml}$ of penicillin and $100 \mathrm{mg} / \mathrm{ml}$ of streptomycin (PAA).

\section{Monolayer culture and doubling time calculation}

Cells were cultured as monolayer at a density of $10^{4}$ cells $/ \mathrm{cm}^{2}$ in T-25 tissue culture flasks (Orange Scientific, Belgium). Cultures were maintained at $37^{\circ} \mathrm{C}$ in a humidified atmosphere and $5 \% \mathrm{CO}_{2}$. Cells were harvested by trypsinizing cultures with
$0.25 \%$ trypsin and $0.03 \%$ ethylene diamine tetraacetic acid (EDTA) (Sigma) in phosphate buffer saline (PBS) (Sigma).

Three passages after cells thawing, the cells were cultured at a density of $2 \times 10^{4}$ per well in multiwell plates (24 wells/plate) (Orange). At 24 hours intervals, the cells from triplicate wells were removed by $1 \mathrm{mM}$ EDTA/0.25\% Trypsin $(\mathrm{w} / \mathrm{v})$ treatment and counted in a hemocytometer. An average of nine counts was used to define each point. Doubling time was calculated using the slope of the logarithmic phase of growth curve.

\section{Spheroid culture and volume doubling time calculation}

Spheroids were initiated using the liquid overlay technique. $5 \times 10^{5}$ cells were seeded into $100 \mathrm{~mm}$ petridishes (Orange) coated with a thin layer of $1 \%$ agar (Merck) containing 10 $\mathrm{ml}$ of MEM supplemented with $10 \%$ FBS. The plates were incubated at $37^{\circ} \mathrm{C}$ in a humidified atmosphere and $5 \% \mathrm{CO}_{2}$. Half of the culture medium was replaced with fresh culture medium twice per week (Khoei et al. 2004). At 3 days intervals, two vertical diameters of 20 random spheroids were measured using inverted microscope. Spheroid volumes were calculated by Eq. 1:

$$
v=\frac{a b^{2} \pi}{6}
$$

where "a" and "b" are the small and large diameters of each spheroid, respectively. Volume doubling time was calculated using the slope of the logarithmic phase of spheroid growth curve.

\section{MTT assay}

After 19 days, spheroids with $350 \mu \mathrm{m}$ of diameter were dispersed and plated into 96 well plates (Orange) and incubated for $24 \mathrm{~h}$ at $37^{\circ} \mathrm{C}$ in $5 \% \mathrm{CO}_{2}$. Cells were subsequently exposed to incremental concentration of resveratrol $(50-500 \mu \mathrm{M})$ in $200 \mu \mathrm{l} \mathrm{MEM}$ and incubated for $72 \mathrm{~h}$. Resveratrol was dissolved in ethanol and the final concentration of ethanol added to the medium was $0.1 \%(\mathrm{v} / \mathrm{v})$. The same concentration of ethanol was added to the control cultures of cells. Then, $20 \mu \mathrm{l}$ 3-(4,5-dimethylthiazol-2-Yl)-2,5-diphenyltetrazolium bromide (MTT) $(0.5 \mathrm{mg} / \mathrm{ml})$ was added to each well protected from light and incubated at $37^{\circ} \mathrm{C}$ for $3.5 \mathrm{~h}$. Formosan crystals were dissolved by adding $200 \mu \mathrm{l}$ of DMSO for $15 \mathrm{~min}$. An ELISA plate reader was used to read the absorbance with a wave length of $570 \mathrm{~nm}$ and $630 \mathrm{~nm}$ which served as a reference (Nezamtaheri et al. 2012).

\section{Irradiation procedure}

The irradiation of DU145 was performed using x-ray beams at the Shohadaye Tajrish Hospital. For all cells, irradiation 
treatments were done under a calibrated $6 \mathrm{MV}$ x-ray beam from a Varian linear accelerator (Varian Associates Inc., California, USA) with 2 Gy radiation dose. The U87MG spheroids in T-25 flask were irradiated at room temperature. The flasks were completely filled with medium. For the $\mathrm{x}$ ray setup, the irradiation was performed at $100 \mathrm{~cm}$ source to surface distance (SSD) using a $40 \mathrm{~cm} \times 40 \mathrm{~cm}$ field size (dose rate 1 centiGray/Monitor Unit (cGy/MU)) and under a full scatter condition. The Linear Energy Transfer (LET) of $6 \mathrm{MV}$ x-ray radiation with $28.13 \mathrm{~mm}$ practical range at target was $213.29 \mathrm{ev} / \mu \mathrm{m}$.

\section{Spheroid treatment}

Cells were cultured for multicellular spheroid formation. On day 21, spheroids with diameter $350 \mu \mathrm{m}$ were treated with IUdR and/or resveratrol and/or 2 Gy of $6 \mathrm{MV}$ x-ray radiation. IUdR and/or resveratrol treatment were done for 1 volume doubling time ( 67 hours) at $37^{\circ} \mathrm{C}$ in a humidified atmosphere and $5 \% \mathrm{CO}_{2}$. As control, one group was treated with $0.1 \%$ ethanol. Other treatments were performed according to following group:

1. Treated with resveratrol (IC10:20 $\mu \mathrm{M})$ for 67 hours

2. Treated with IUdR $(1 \mu \mathrm{M})$ for 67 hours

3. Irradiated with $\mathrm{x}$-ray (2 Gy)

4. Treated simultaneously with resveratrol $(20 \mu \mathrm{M})$ and $\operatorname{IUdR}(1 \mu \mathrm{M})$ for 67 hours

5. Treated with resveratrol $(20 \mu \mathrm{M})$ for 67 hours then irradiated with $\mathrm{x}$-ray (2 Gy)

6. Treated with IUdR $(1 \mu \mathrm{M})$ for 67 hours then irradiated with x-ray (2 Gy)

7. Treated simultaneously with resveratrol $(20 \mu \mathrm{M})$ and IUdR $(1 \mu \mathrm{M})$ for 67 hours then irradiated with $\mathrm{x}$-ray (2 Gy).

The viability of control and treated spheroids were determined using trypan blue dye exclusion assay. Then the cytotoxic effects and DNA damages were measured using colonogenic and alkaline comet assay, respectively.

\section{Trypan blue exclusion assay}

A suspension of treated and control single cells from spheroid cultures were mixed with trypan blue at a ratio of 9:1. After a few minutes the mixture was examined under an inverted microscope (Motic. A251) and the blue cells were considered dead. The percentage of unstained cells out of the total number of cells was the viability of each cell category.

\section{Colonogenic assay}

Irradiated and control single cell suspensions from spheroid culture were seeded in $60 \mathrm{~mm}$ petridishes (Orange) and grown in MEM containing 10\% FBS. The cells were incu- bated at $37^{\circ} \mathrm{C}$ in a humidified atmosphere of $5 \% \mathrm{CO}_{2}$ for ten days. After this interval, the colonies which contained a minimum of 50 cells were counted by an inverted phase microscope and the plating efficiency was determined by Eq. 2.

$$
P E(\%)=\frac{\text { Number of colonies counted }}{\text { Number of cells seeded }} \times 100
$$

\section{Alkaline comet assay}

DNA fragmentation was assessed using single cell gel electrophoresis (Comet) assay, previously optimized by our group (Fazeli et al. 2007). Comet tail moment was determined by measuring the fluorescence intensity using the Comet score software.

\section{Statistical analysis}

Data were given as mean \pm SEM with $n$ denoting the number of experiment. Analysis was performed using one-way analysis of variance (ANOVA) followed by Tukey's test as the post hoc analysis using SPSS version 16. The value of $p<0.05$ was considered to be significant.

\section{Results}

\section{Cell characteristics}

The U87MG glioblastoma cell line grows as a monolayer on tissue culture flasks. The growth curve of these cells in the monolayer culture is shown in Figure 1. The population

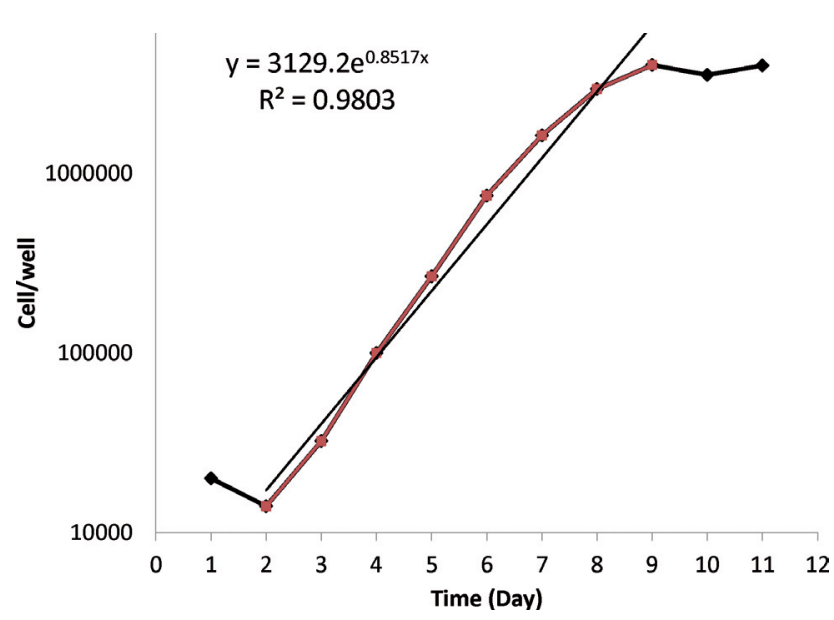

Figure 1. Growth curve of U87MG cell line in the monolayer culture. An average of nine counts was used to define each point. The values are the mean \pm SEM of three experiments. 


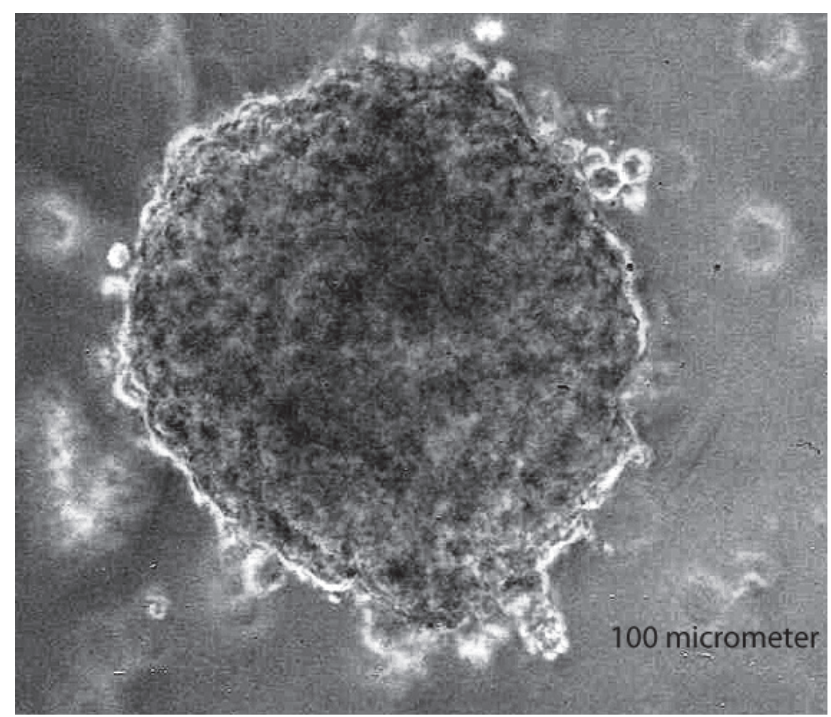

Figure 2. Phase contrast micrograph of U87MG cell spheroid with $350 \mu \mathrm{m}$ diameter on day 21 after culture initiation. Magnification $\times 10$.

doubling time calculated from this curve was approximately $18.24 \pm 0.84$ hours.

\section{Spheroid culture}

Spheroids were cultured using the liquid overlay technique. The volume doubling time (the period of time required for a spheroid to double in volume) calculated from the spheroid growth curve was approximately $67 \pm 0.91$ hours (Neshasteh-Riz et al. 2008). Figure 2 shows the phase contrast micrographs of this spheroid 21 days after spheroid culture of diameter $350 \mu \mathrm{m}$.
Viability assay

Immediately after cell treatment with resveratrol (Res), IUdR and radiation, cells were counted and viability was determined using the trypan blue dye exclusion assay. Figure 3 shows the effect of resveratrol, IUdR, radiation and combination of them on the viability of U87MG spheroids. As can be seen, neither of them has any effect on the viability of cells in spheroid culture $(p>0.05)$.

\section{MTT assay}

The effect of resveratrol on the viability of U87MG cells was determined by MTT assay is shown in Figure 4. The half maximal inhibitory concentration (IC50) for resveratrol was calculated as $60 \mu \mathrm{M}$; IC10 $(20 \mu \mathrm{M})$ was used for treatment of cells.

\section{Effects of resveratrol, $I U d R$ and $x$-ray radiation on colony forming ability}

The cell response to drugs and radiation in terms of colony formation was studied by applying $20 \mu \mathrm{M}$ resveratrol, $1 \mu \mathrm{M}$ IUdR and 2 Gy of $6 \mathrm{MV} \mathrm{x}$-ray radiation on the basis of 7 groups described in the section of Materials and Methods. Plots of plating efficiency versus different treatments for 21 days old spheroid cultures are shown in Figure 5. In $350 \mu \mathrm{M}$ spheroids, $20 \mu \mathrm{M}$ of resveratrol didn't reduce the plating efficiency in comparison with control $(p>0.05)$. In contrast, $1 \mu \mathrm{M}$ IUdR and 2 Gy $\mathrm{x}$-ray radiation separately reduced the colony forming ability of the cells $(p<0.001)$. The plating efficiency (PE) of treated spheroids with resveratrol+IUdR was reduced in comparison with spheroids treated with IUdR or resveratrol alone $(p<0.001)$. Furthermore, colony forma-

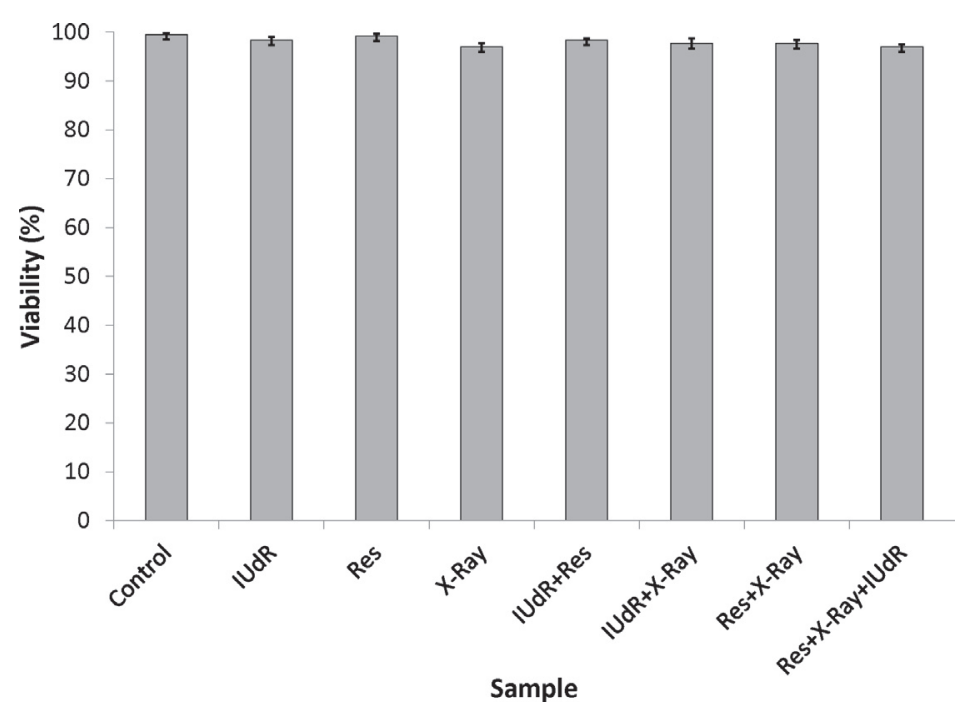

Figure 3. Effects of resveratrol (Res), IUdR and $6 \mathrm{MV}$ $\mathrm{x}$-ray radiation on viability of U87MG cells in spheroid culture. Immediately after treatments, viability of the cells was assayed using trypan blue dye exclusion assay. The values are the mean \pm SEM of three experiments. 


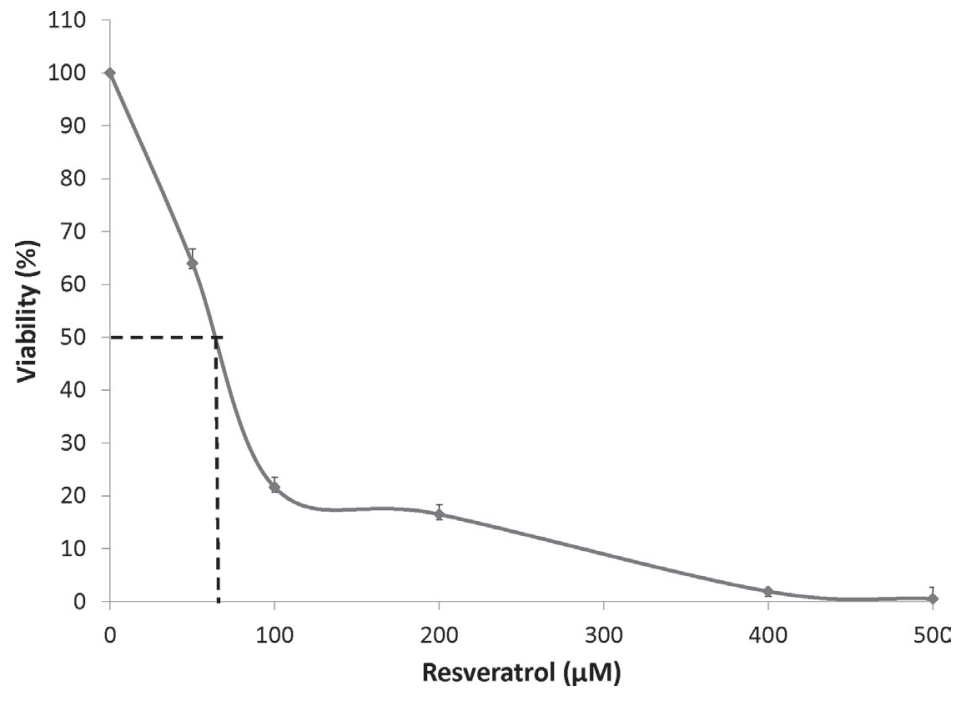

Figure 4. Cell viability measured with MTT in U87MG spheroid culture. The values of optical density measured at $\lambda=570 \mathrm{~nm}$ are reported as percentage with respect to the optical density registered for untreated control. The latter considered as $100 \%$ of cell viability. The values are the mean \pm SEM of three experiments performed in triplicate. tion ability was reduced significantly in groups treated with $\mathrm{IUdR}+\mathrm{x}$-ray in comparison with $\mathrm{x}$-ray radiated spheroids $(p<0.001)$, but there is not significantly difference between the $\mathrm{PE}$ of spheroids treated with resveratrol+x-ray compared with irradiated spheroids $(p=0.957)$. Finally, the colony forming ability of spheroids treated with resveratrol+IUdR and then irradiated with 2 Gy of $6 \mathrm{MV}$ x-ray radiation was significantly reduced in compared with spheroids treated with IUdR+X-ray or resveratrol+x-ray $(p<0.001)$.

\section{Effects of resveratrol, IUdR and $x$-ray radiation on DNA damages}

The average of tail moments in each category of cells was used as an indication of DNA damages. Figure 6 shows the distribution of tail moments in control and treated spheroids. As it can be seen, the calculated tail moments in spheroids treated with resveratrol are as much as control group $(p=0.696)$. But treating spheroids with IUdR or $\mathrm{X}-$ ray and combination of them significantly increased DNA damage compared with control group $(p=0.002$ and $p<$ 0.001 , respectively). Surprisingly, treating spheroids with resveratrol+x-ray increased DNA damages compared with spheroids exposed to $x$-ray beam $(p<0.001)$. However the extent of DNA damages induction due to IUdR+x-ray was significantly more than resveratrol+x-ray $(p<0.001)$. Finally, the DNA damages were significantly increased in the presence of resveratrol $+\mathrm{IUdR}+\mathrm{x}$-ray as compared to the both groups of resveratrol $+\mathrm{x}-$ ray and $\mathrm{IUdR}+\mathrm{x}$-ray $(p<0.001)$.

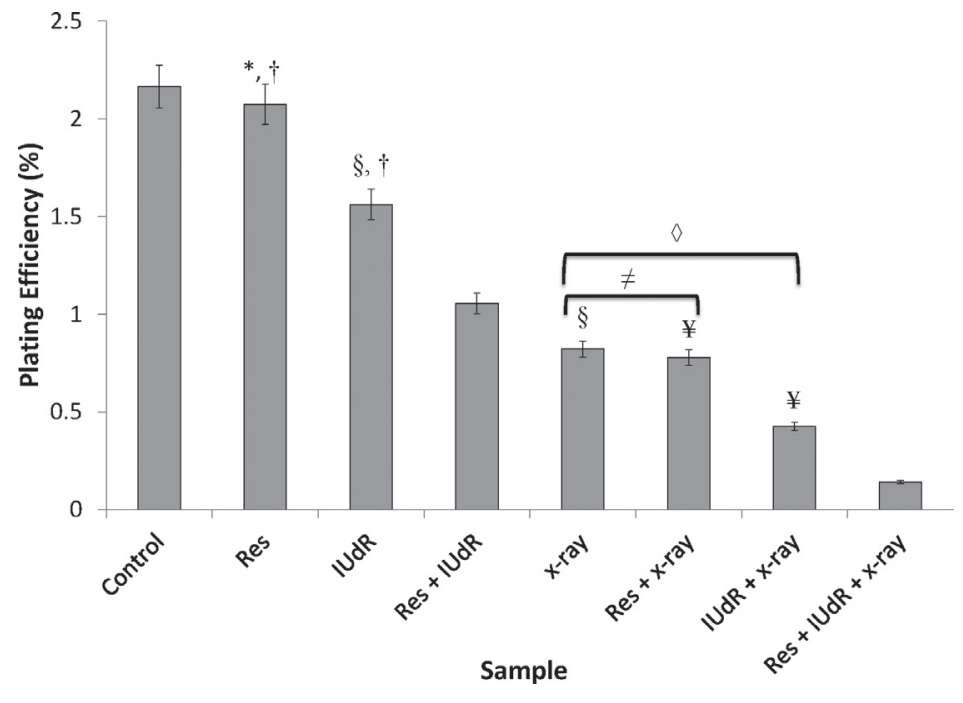

Figure 5. Plating efficiency of U87MG spheroids treated with resveratrol and IUdR alone or in combination with 6 $\mathrm{MV} \mathrm{x}$-ray beam. The values are the mean \pm SEM of three experiments. ${ }^{\star} p>0.05 v s$. control, $\$ p<0.001 v s$. control, $\dagger p<0.001 v s$. IUdR+resveratrol, $\neq p=0.957, \diamond p<0.001$, $¥ p<0.001 v s$. IUdR+resveratrol+x-ray. 


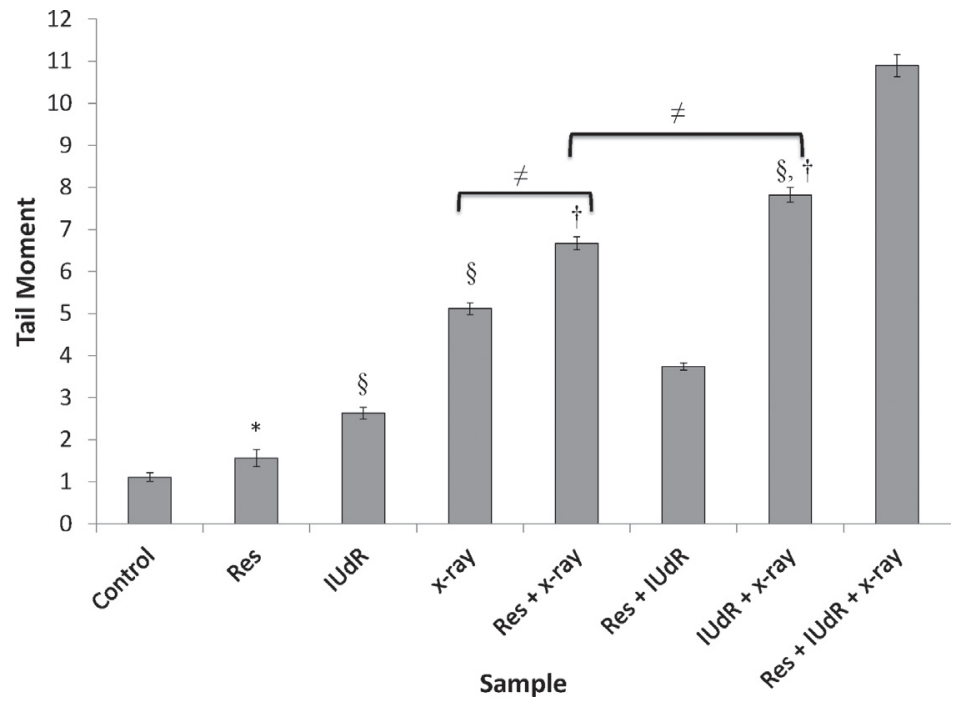

Figure 6. Calculated tail moments after treatment with resveratrol, IUdR, x-ray radiation and combination of them. The values are the mean \pm SEM of three experiments. ${ }^{*} p=0.696 v s$. control, $₫ p<0.005 v s$. control, $\neq$ $p<0.001, \dagger p<0.001 v s$. IUdR+resveratrol+x-ray.

\section{Discussion}

Hypoxic cells are one the main characteristics of advanced tumors which is caused by the structural and functional abnormalities of the tumor microvasculature, rapid expansion of tumor mass and tumor associated anemia (Vaupel et al. 2001). The first response to hypoxic condition is up regulating of HIF-1 protein (Dachs et al. 1997; Fruehauf and Meyskens 2007). It will decrease apoptosis, increase tumor growth, induce VEGF and reduce S-phase indices (Lee et al. 2009). It was revealed that disrupting the progression of $\mathrm{G}_{1} / \mathrm{S}$ phase during hypoxia is due to inactivation of CDKs (Sangfelt et al. 1999). Resveratrol is a natural polyphenolic phytoalexin found in grapes, peanuts and various other fruits (Athar et al. 2007). Recent studies show that resveratrol induces apoptosis (Jiang et al. 2005), suppresses the angiogenesis and tumor growth (Tseng et al. 2004) and decreases HIF-1 levels in different tumor cell line (Cao et al. 2004; Wu et al. 2008; Trapp et al. 2010). Zhang et al. (2005) showed that resveratrol inhibits HIF-1 $\alpha$ protein expression via regulating both protein translation and HIF-1a protein degradation. Iododeoxyuridine is a halogenated pyrimidine that can be incorporated into DNA instead of thymidine during DNA replication. This halogenated pyrimidine is considered as clinical radiosensitizer, where the extent of radiosensitization correlates directly with the level of halogenated pyrimidineDNA incorporation (Kinsella et al. 1987; Lawrence et al. 1990; Miller et al. 1992).

Multicellular tumor spheroids are a well-established 3-D in vitro model system that reflects the pathophysiological in vivo situation in tumor system. Spheroids show more resistance to ionizing radiation as compared to monolayer cultures (Olive and Durand 1985; Bates et al. 2000). Furthermore it has been revealed that as spheroids grow, IUdR absorption is decreased. Both of mentioned results have been attributed to presence of hypoxic and $\mathrm{G}_{0}$ cells in spheroids.

It was reported that treatment of cells with IUdR alone or in combination with radiation could increase DNA damage in glioblastoma cell line (Phillips 1995) and by enhancing the IUdR incorporation into DNA, damages will increase. In this study we evaluated that resveratrol can increase the radiosensitization of $350 \mu \mathrm{m}$ glioma spheroids treated with IUdR.

As shown in Figure 2, $20 \mu \mathrm{M}$ resveratrol, $1 \mu \mathrm{M}$ IUdR and 2 Gy of $\mathrm{x}$-ray radiation had no significant effects on viability of the cells. Consistent with previous studies (Khoei et al. 2011), our data showed that treatment of U87MG glioblastoma spheroids with IUdR or radiation and a combination of them can increase DNA damages and reduce colony forming ability. Figure 5 and 6 indicated that $20 \mu \mathrm{M}$ resveratrol had no effect on colony formation ability and DNA damages. Also, combination treatment with resveratrol and 2 Gy of x-ray radiation increased the DNA damages, but didn't change the colony formation ability compared with irradiated group alone. This difference between comet and clonogenic assays results could be due to the time. Alkaline comet assay shows single strand breaks (SSB), double strand breaks (DSB) and apurinic/apyrimidinic (AP) site. In this study, DNA damages were measured immediately after treatment. Therefore, all damages could be detected using comet assay whereas colony formation ability was assayed after ten days. Therefore, cells had enough time to repair DNA and cell damages. Hercbergs et al. (2011) shown that more than $95 \%$ of DSB were repaired within 300 minutes after the $\mathrm{x}$-ray radiation in U87MG cell line.

Numerous studies have shown that resveratrol can activate apoptotic cascade in high dose. It is able to initiate apoptosis by different pathway such as the mitochondrial 
pathway (Jiang et al. 2005). More ever it is shown that resveratrol could arrest cell cycle in $\mathrm{G}_{2} / \mathrm{M}$ phase which is a sensitive phase against radiation (Joe et al. 2002).

Effect of resveratrol on U87MG spheroids should be investigated. But we speculate that resveratrol can increase the cell cycle arrest in $\mathrm{G}_{2} / \mathrm{M}$ phase and also the number of apoptotic cells. But the difference between comet and clonogenic assays results could be due to the time. Cells had enough time to repair DNA damages and therefore cellular damages in colonogenic assay. In addition, the results showed that resveratrol could increase DNA and cell damages induced by radiation in spheroids treated with IUdR radiosensitizer. These results are very similar to our previous study on the role of 2-methoxyestradiol on the cytotoxic effects and DNA damages of iododeoxyuridine and ${ }^{60} \mathrm{Co}$ radiation in spheroid culture of U87MG glioblastoma cell line (Khoei et al. 2011). This might be due to HIF-1 a protein inhibition effect of resveratrol. By suppressing the activity and expression of HIF-1 $\alpha$, resveratrol caused an increase in cell progression into S phase and IUdR absorption and finally radiosensitization.

\section{Conclusion}

Combined treatment with resveratrol and X-ray significantly increased DNA and cell damages caused by IUdR. Our findings support the pretreatment of cells with resveratrol+IUdR before radiation with $6 \mathrm{MV} \mathrm{x}$-ray to enhance tumor radiosensitization and possibly improve the therapeutic index for radiation.

Acknowledgment. This work was supported by grants No. 18033 from the Razi Drug Research Centre of Iran University of Medical Sciences.

\section{References}

Aluyen J. K., Ton Q. N., Tran T., Yang A. E., Gottlieb H. B., Bellanger R. A. (2012): Resveratrol: potential as anticancer agent. J. Diet. Suppl. 9, 45-56 http://dx.doi.org/10.3109/19390211.2011.650842

Athar M., Back J. H., Tang X., Kim K. H., Kopelovich L., Bickers D. R., Kim A. L. (2007): Resveratrol: a review of pre-clinical studies for human cancer prevention. Toxicol. Appl. Pharmacol. 224, 274-283 http://dx.doi.org/10.1016/j.taap.2006.12.025

Bates R. C., Edward N. S., Yates J. D. (2000): Spheroids and cell survival. Crit. Rev. Oncol. Hematol. 36, 61-74 http://dx.doi.org/10.1016/S1040-8428(00)00077-9

Benitez D. A., Pozo-Guisado E., Alvarez-Barrientos A. , FernandezSalguero P. M., Castellon E. A. (2007): Mechanisms involved in resveratrol-induced apoptosis and cell cycle arrest in prostate cancer-derived cell lines. J. Androl. 28, 282-293 http://dx.doi.org/10.2164/jandrol.106.000968

Cao Z., Fang J., Xia C., Shi X., Jiang B. H. (2004): Trans-3,4,5'-Trihydroxystibene inhibits hypoxia-inducible factor lalpha and vascular endothelial growth factor expression in human ovarian cancer cells. Clin. Cancer Res. 10, 5253-5263 http://dx.doi.org/10.1158/1078-0432.CCR-03-0588

Dachs G. U., Patterson A. V., Firth J. D., Ratcliffe P. J, Townsend K. M., Startford I. J., Harris A. L. (1997): Targeting gene expression to hypoxic tumor cells. Nat. Med. 3, 515-520 http://dx.doi.org/10.1038/nm0597-515

Fazeli G. R., Khoei S., Nikoofar A. R., Goliaei B. (2007): Reduced DNA damage in tumor spheroids compared to monolayer cultures exposed to ionizing radiation. Iran. J. Radiat. Res. 5, 63-69

Fruehauf J. P., Meyskens F. L. (2007): Reactive oxygen species: a breath of life or death? Clin. Cancer Res. 13, 789-794 http://dx.doi.org/10.1158/1078-0432.CCR-06-2082

Hercbergs A. H., Lin H. Y., Davis F. B., Davis P. J., Leith J. T. (2011): Radiosensitization and production of DNA double-strand breaks in U87MG brain tumor cells induced by tetraiodothyroacetic acid (tetrac). Cell Cycle 10, 352-357 http://dx.doi.org/10.4161/cc.10.2.14641

Iida T., Mine S., Fujimoto H., Suzuki K., Minami Y., Tanaka Y. (2002): Hypoxia-inducible factor-1alpha induces cell cycle arrest of endothelial cells. Genes Cells 7, 143-149 http://dx.doi.org/10.1046/j.1356-9597.2001.00512.x

Jiang H., Zhang L., Kuo J., Kuo K., Gautam S.C, Groc L., Rodriguez A. I., Koubi D., Hunter T. J., Corcoran G. B., Seidman M. D., Levine R. A. (2005): Resveratrol-induced apoptotic death in Human U251 Glioma Cells. Mol. Cancer Ther. 4, 554-561

http://dx.doi.org/10.1158/1535-7163.MCT-04-0056

Joe A. K., Liu H., Suzui M., Vural M. E., Xiao D., Weinstein I. B. (2002): Resveratrol induces growth inhibition, S-phase arrest, apoptosis, and changes in biomarker expression in several human cancer cell lines. Clin. Cancer Res. 8, 893-903

Kaur B., Khwaja F. W., Severson E. A., Matheny S. L., Brat D. J., Van Meir E. G. (2005): Hypoxia and the hypoxia-inducible-factor pathway in glioma growth and angiogenesis. Neuro. Oncol. $7,134-153$

http://dx.doi.org/10.1215/S1152851704001115

Ke Q., Costa M. (2006): Hypoxia-inducible factor-1 (HIF-1). Mol. Pharmacol. 70, 1469-1480. http://dx.doi.org/10.1124/mol.106.027029

Khoei S., Delfan S., Neshasteh-Riz A., Mahdavi S. R. (2011): Evaluation of the combined effect of $2 \mathrm{ME} 2$ and (60)Co on the inducement of DNA damage by IUdR in a spheroid model of the $\mathrm{u} 87 \mathrm{mg}$ glioblastoma cancer cell line using alkaline comet assay. Cell J. 13, 83-90

Khoei S., Goliaei B., Neshasteh-Riz A., Deizadji A. (2004): The role of heat shock protein 70 in the thermoresistance of prostate cancer cell line spheroids. FEBS Lett. 561, 144-148 http://dx.doi.org/10.1016/S0014-5793(04)00158-9

Kim D. H., Hossain M. A., Kim M. Y., Kim J. A., Yoon J. H., Suh H. S., Kim G. Y., Choi Y. H., Chung H. Y., Kim N. D. (2013): A novel resveratrol analogue, HS-1793, inhibits hypoxia-induced HIF-1alpha and VEGF expression, and migration in human prostate cancer cells. Int. J. Oncol. 43, 1915-1924 
Kim J. A., Kim D. H., Hossain M. A., Kim M. Y., Sung B., Yoon J. H., Suh H., Jeong T. C., Chung H. Y., Kim N. D. (2014): HS-1793, a resveratrol analogue, induces cell cycle arrest and apoptotic cell death in human breast cancer cells. Int. J. Oncol. 44, 473-480 http://dx.doi.org/ 10.3892/ijo.2013.2207

Kinsella T. J., Dobson P. P., Mitchell J. B., Fornace A. J. Jr (1987) Enhancement of X ray induced DNA damage by pre-treatment with halogenated pyrimidine analogs. Int. J. Radiat. Oncol. Biol. Phys. 13, 733-739 http://dx.doi.org/10.1016/0360-3016(87)90292-6

Kinsella T. J., Kinsella M. T., Seo Y., Berk G. (2007): 5-iodo-2-pyrimidinone-2'-deoxyribose-mediated cytotoxicity and radiosensitization in U87 human glioblastoma xenografts. Int. J. Radiat. Oncol. Biol. Phys. 69, 1254-1261

Krick S., Eul B. G., Hanze J., Savai R., Grimminger F., Seeger W., Rose F. (2005): Role of hypoxia-inducible factor-1alpha in hypoxia-induced apoptosis of primary alveolar epithelial type II cells. Am. J. Respir. Cell. Mol. Biol. 32, 395-403 http://dx.doi.org/10.1165/rcmb.2004-0314OC

Lawrence T. S., Davis M. A., Maybaum J., Stetson P. L., Ensminger W. D. (1990): The dependence of halogenated pyrimidine incorporation and radiosensitization on the duration of drug exposure. Int. J. Radiat. Oncol. Biol. Phys. 18, 1393-1398 http://dx.doi.org/10.1016/0360-3016(90)90313-9

Lee S., Rouhi P., Jensen L., Zhang D., Ji H., Hauptmann G., Ingham P., Cao Y. (2009): Hypoxia-induced patological angiogenesis mediates tumor cell dissemination, invasion and metastasis in a zebrafish tumor model. Proc. Natl. Acad. Sci. USA 106, 19485-19490 http://dx.doi.org/10.1073/pnas.0909228106

Menrad H., Werno C., Schmid T., Copanaki E., Deller T., Dehne N., Brune B. (2010): Roles of hypoxia-inducible factor-1alpha (HIF-1alpha) versus HIF-2alpha in the survival of hepatocellular tumor spheroids. Hepatology 51, 2183-2192 http://dx.doi.org/10.1002/hep.23597

Miller E. M., Fowler J. F., Kinsella T. J. (1992): Linear-quadratic analysis of radiosensitization by halogenated pyrimidines: $i$. radiosensitization of human colon cancer cells by iododeoxyuridine. Radiat. Res. 131, 81-89 http://dx.doi.org/10.2307/3578320

Neshasteh-Riz A., Saki M., Khoei S. (2008): Cytogenetic damages from iododeoxyuridine -induced radiosensitivity with and without methoxyamine in human glioblastoma spheroids. Cell. J. 10, 57-64

Nezamtaheri M. S., Khoei S., Nikoofar A. R., Goliaei B. (2012): Comparison of radiosensitizing effect of Resveratrol on monolayer and spheroid culture of DU145 prostatic cell line. Int. J. Radiat. Res. 10, 117-181

Olive P. L., Durand R. E. (1985): Effect of intercellular contact on DNA conformation, radiation-induced DNA damage and mutation in chinese hamster V79 cells. Radiat. Res. 101, 94-101 http://dx.doi.org/10.2307/3576306

Phillips T. L. (1995): Iododeoxyuridine radiosensitization of human glioblastoma cells. Cancer J. Sci. Am. 1, 112-113
Sangfelt O., Erickson S., Castro J., Heiden T., Gustafsson A., Einhorn S., Grander D. (1999): Molecular mechanisms underlying interferon-alpha-induced G0/G1 arrest: CKI-mediated regulation of G1 Cdk-complexes and activation of pocket proteins. Oncogene 18, 2798-2810 http://dx.doi.org/10.1038/sj.onc.1202609

Speth P. A., Kinsella T. J., Chang A. E., Klecker Jr., Belanger K., Smith S., Rowland J., Cupp J. E., Collins J. M. (1989): Iododeoxyuridine (IdUrd) incorporation into DNA of human hematopoietic cells, normal liver and hepatic metastases in man: as a radiosensitizer and as a marker for cell kinetic studies. Int. J. Radiat. Oncol. Biol. Phys. 16, 1247-1250 http://dx.doi.org/10.1016/0360-3016(89)90292-7

Trapp V., Parmakhtiar B., Papazian V., Willmott L., Fruehauf J. P., (2010): Anti-angiogenetic effects of resveratrol mediated by decreased VEGF and increases TSP1 expression in melanomaendothelial cell co-culture. Angiogenesis 13, 305-315 http://dx.doi.org/10.1007/s10456-010-9187-8

Tseng S. H., Lin S. M., Chen J. C., Su Y. H., Huang H. Y., Chen C. K., Lin P. Y., Chen Y., (2004): Resveratrol suppresses the angiogenesis and tumor growth of gliomas in rats. Clin. Cancer Res. 10, 2190-2202 http://dx.doi.org/10.1158/1078-0432.CCR-03-0105

Van Meir E. G., Hadjipanayis C. G., Norden A. D., Shu H. K., Wen P. Y., Olson J. J. (2010): Exciting new advances in neuro-oncology: the avenue to a cure for malignant glioma. CA. Cancer J. Clin. 60, 166-193 http://dx.doi.org/10.3322/caac.20069

Vaupel P., Thews O., Hoeckel M. (2001): Treatment resistance of solid tumors: role of hypoxia and anemia. Med. Oncol. 18, 243-259

Wu H., Liang X., Fang Y., Qin X., Zhang Y., Liu J. (2008): Resveratrol inhibits hypoxia-induced metastasis potential enhancement by restricting hypoxia-induced factor-1 alpha expression in colon carcinoma cells. Biomed. Pharmacother. 62, 613-621 http://dx.doi.org/10.1016/j.biopha.2008.06.036

Yoon J, Juhn K. M., Ko J. K., Yoon S. H., Ko Y., Lee C. Y., Lim J. H. (2013): Effects of oxygen tension and IGF-I on HIF-1alpha protein expression in mouse blastocysts. J. Assist. Reprod. Genet. 30, 99-105 http://dx.doi.org/10.1007/s10815-012-9902-z

Yuhas J. M., Li A. P. (1978): Growth fraction as the major determinant of multicellular tumor spheroid growth rates. Cancer Res. 38, 1528-1532 http://cancerres.aacrjournals.org/content/38/6/1528

Zhang Q., Tang X., Lu Q. Y., Zhang Z. F., Brown J., Le A. D. (2005): Resveratrol inhibits hypoxia-induced accumulation of hypoxiainducible factor-1alpha and VEGF expression in human tongue squamous cell carcinoma and hepatoma cells. Mol. Cancer Ther. 4, 1465-1474 http://dx.doi.org/10.1158/1535-7163.MCT-05-0198

Received: February 2, 2014

Final version accepted: July 22, 2014

First published online: November 4, 2014 